Article

\title{
Fermentation of Cucumber Extract with Hydromagnesite as a Neutralizing Agent to Produce an Ingredient for Dermal Magnesium Products
}

\author{
Van Khanh Nguyen ${ }^{1, *(\mathbb{D})}$, Tam Tran ${ }^{2}$, Tony Crimmins ${ }^{2,3}$, Van-Tri Luong ${ }^{2,4}$ and \\ Ho Young Kang ${ }^{1, *}$ \\ 1 Department of Microbiology, Pusan National University, Busan 46241, Korea \\ 2 EcoMag Ltd., Chatswood, NSW 2067, Australia; tam@ecomagnesium.com (T.T.); \\ t.crimmins@abundantproduce.com (T.C.); vantri.luong@unsw.edu.au (V.-T.L.) \\ 3 Abundant Natural Health Pty, Abundant Produce Ltd., Chatswood, NSW 2067, Australia \\ 4 Particles and Catalysis Research Group, School of Chemical Engineering, University of New South Wales, \\ Sydney, NSW 2052, Australia \\ * Correspondence: khanhnv88@pusan.ac.kr (V.K.N.); hoykang@pusan.ac.kr (H.Y.K.); \\ Tel.: +82-51-510-2271 (V.K.N.); +82-51-510-1757 (H.Y.K.)
}

Received: 10 April 2019; Accepted: 24 May 2019; Published: 25 May 2019

\begin{abstract}
Magnesium is an essential element involved in various biochemical processes in the human body. In addition to oral supplementation, topical magnesium application is another conventional form of magnesium delivery for the treatment of skin diseases and muscle inflammation. Cucumber extract is a well-known superfood for human skin. It has been widely used in various skincare product lines because of its known benefits to the skin. The benefit of cucumber extract to the human skin would be significantly enhanced if the cucumber extract was fermented to convert the reducing sugars to beneficial organic acids. In this study, we developed a protocol for lactic acid fermentation of cucumber extract using hydromagnesite as a neutralizing agent. Various lactic acid bacteria were screened for fermentation of cucumber extract. The best fermenting performance was observed with Lactobacillus paracasei, which could convert approximately $13 \mathrm{~g} / \mathrm{L}$ of reducing sugars (glucose and fructose) to lactic acid and a minor amount of acetic acid within 2 days of incubation. The final fermented cucumber extract contains magnesium in the form of salts of organic acids, which have high absorption ability and bioavailability. The product is a potent ingredient for producing dermal magnesium products.
\end{abstract}

Keywords: lactic acid bacteria; cucumber extract; magnesium; fermentation

\section{Introduction}

Natural antioxidants extracted from plants and fruits have attracted much attention from scientists and cosmetics manufacturers. Many of these antioxidants have been used in making skincare formulations and have contributed to skin rejuvenation [1]. Cucumber extracts, which are rich in vitamins, such as vitamin A and C, and antioxidants, have been proven to have various effects on the skin, such as soothing of irritated skin, moisturization, anti-inflammatory, sebum secretion inhibitory, and melanin synthesis inhibitory effects [2-4]. As a superfood for the skin, cucumber extract has been added to various skin care products, such as toner, lotion, and cream. However, it also contains a significant amount of sugars, such as glucose and fructose $[5,6]$, which do not provide any benefit to the skin. These sugars are a potential source of fermentation to produce lactic acid, which is a potent compound in skin disease treatment [7]. Lactic acid fermentation of cucumber extract is usually hindered by its low $\mathrm{pH}$, caused by the production of lactic acid [6]. A neutralizing agent is 
typically required to adjust the $\mathrm{pH}$ of cucumber extract to favor the conversion of sugars to lactic acid. The common neutralizing agents used in lactic acid fermentation, such as $\mathrm{NaOH}, \mathrm{Na}_{2} \mathrm{CO}_{3}, \mathrm{KOH}$, $\mathrm{NH}_{4} \mathrm{OH}, \mathrm{Ca}(\mathrm{OH})_{2}$, and $\mathrm{CaCO}_{3}$, enrich the final fermented cucumber extract in $\mathrm{Na}^{+}, \mathrm{K}^{+}, \mathrm{NH}_{4}{ }^{+}$, and $\mathrm{Ca}^{2+}$, which do not provide any extra value in terms of skincare.

Magnesium is a metal element defined by the symbol $\mathrm{Mg}$ and belongs to Group 2 (alkaline earth metals) of the periodic table. $\mathrm{Mg}$ is a mineral crucial for human health. It plays a vital role in controlling blood pressure, ensuring normal nerve and muscle functions, and supporting psychological functions and energy production [8,9]. Chronic Mg deficiency could result in many disorders, such as cardiovascular diseases, asthma, diabetes, and osteoporosis [9-11]. Suboptimal Mg intake has been recorded in broad sections of the population in many industrialized countries owing to changes in food preparation and nutritive behavior [12]. Oral supplementation or dietary intake are the general ways to overcome $\mathrm{Mg}$ deficiency and to ameliorate inflammatory disorders. However, topical $\mathrm{Mg}$ application through therapies that have been used for several centuries has been proven to be effective in treating skin diseases [13]. A previous study indicated that hair follicles significantly contributed to the permeation of topically applied $\mathrm{Mg}$ through the human skin [14]. In addition, the efficacy of $\mathrm{Mg}$ supplementation generally depends on the bioavailability of $\mathrm{Mg}$ forms. Organic acid-binding forms of $\mathrm{Mg}$, such as $\mathrm{Mg}$ lactate, $\mathrm{Mg}$ citrate, and $\mathrm{Mg}$ gluconate, are more bioavailable than inorganic $\mathrm{Mg}$ salts $[8,9,15,16]$.

This study aimed to develop a potent ingredient for skincare purposes based on the combination of cucumber extract and $\mathrm{Mg}$ in a unique product through lactic acid fermentation. This scheme took advantages of fermenting the cucumber extract rich in citric acid to convert available sugars to lactic acid. Hydrated magnesium carbonate, the familiar form of $\mathrm{Mg}$ that can be produced at high purity [17], was used as the neutralizing agent in fermentation. Through this process, the $\mathrm{Mg}$ ion was dissociated from hydrated magnesium carbonate to bind to organic acids in the fermented cucumber extract. Sugars were depleted and replaced by lactic acid in the fermented solution. The organic Mg salts in the fermented cucumber extract are considered to have higher bioavailability and can be replaced by the inorganic $\mathrm{MgCl}_{2}$, which is commonly present in dermal $\mathrm{Mg}$ products.

\section{Materials and Methods}

\subsection{Cucumber Extract and Pasteurization}

Cucumber (Cucumis sativus) extract is the fluid surrounding the active cucumber seed. The cucumber was organically bred in Cobbitty, New South Wale, Australia. Cucumber extract was introduced to pasteurization right after harvesting by heating to kill the indigenous bacteria and contaminating bacteria during the harvesting process. Then, it was stored in a sterile container and kept in a freezer at $-20^{\circ} \mathrm{C}$ for the following experiments.

The pasteurization of cucumber extract was tested at a temperature range of 63 to $121^{\circ} \mathrm{C}$ for 1 to $20 \mathrm{~min}$ to identify the lowest temperature and shortest time in which all bacteria are killed, and the physicochemical properties of cucumber extract were maintained optimally. The efficacy of pasteurization was determined through bacterial enumeration on an agar plate. Both heat-treated and non-treated samples were serially diluted using phosphate buffer solution, $\mathrm{pH} 7.2\left(34 \mathrm{~g} / \mathrm{L}\right.$ of $\left.\mathrm{KH}_{2} \mathrm{PO}_{4}\right)$, and an aliquot of $0.2 \mathrm{~mL}$ was spread on yeast extract-eptone-glucose (YEPG) agar plate $[18,19]$. The agar plates were then incubated in an incubator at $25^{\circ} \mathrm{C}$. A colony-forming unit (CFU) was calculated after 3 days of incubation. The chemical ingredients with high purity ( $>99 \%)$ were bought from Sigma Aldrich (Merck KGaA, Darmstadt, Germany). 


\subsection{Hydromagnesite}

Highly pure hydromagnesite or hydrated magnesium carbonate (HMC) is the product of magnesium recovered from bittern or brine [17]. HMC (>99\%) was obtained from EcoMag Ltd. (Chatswood, NSW, Australia). Fine powder of HMC was re-slurried with water at a ratio of 1:3 (weight/weight) before being used for neutralization of cucumber extract.

\subsection{Lactic Acid Bacteria}

A total of 9 obligately homofermentative and facultatively heterofermentative lactic acid bacteria were used in this experiment. Lactobacillus acidophilus KCTC 3164, Lactobacillus delbrueckii subsp. lactis KCTC 3636, Lactobacillus salivarius subsp. salicinius KCTC 3600, Lactobacillus helveticus KCTC 3545, Lactobacillus casei KCTC 13086, Lactobacillus paracasei KCTC 13169, Lactococcus lactis subsp. lactis KCTC 2013 were bought from the Korean Collection for Type Cultures (KCTC). Lactobacillus plantarum, and Pediococcus acidilactici were isolated from regular Korean yogurt. Bacterial cultures were maintained by culturing on an MRS (De Man, Rogosa and Sharpe) (Difco, Becton, Dickinson and Company, Sparks, MD, USA) agar plate. Before fermentation, bacterial culture was transferred to MRS broth medium.

\subsection{Fermentation Experiment}

The fermentation experiment was carried out in $60-\mathrm{mL}$ or $120-\mathrm{mL}$ glass serum bottles sealed with a rubber stopper and an aluminum cap using a Wheaton crimper (Wheaton, IL, USA). Serum bottles were filled with cucumber extract at the working volume of $50 \mathrm{~mL}$. The inoculum ( $1 \%$, volume/volume) was lactic acid bacteria cultivated in MRS for $24 \mathrm{~h}$ at $37^{\circ} \mathrm{C}$. The final cell concentration after inoculation was $3.5 \times 10^{5} \mathrm{CFU} / \mathrm{mL}$. Fermentation was performed by incubation in a shaking incubator at $37^{\circ} \mathrm{C}$ and $180 \mathrm{rpm}$. During fermentation, a 1 to $2 \mathrm{~mL}$ sample was periodically taken and analyzed.

Initially, the original cucumber extract was directly added to the fermentation without neutralization, to test the tolerance of lactic acid bacteria in the original $\mathrm{pH}$ of cucumber extract. Then, fermentation by all bacteria was tested with cucumber extract neutralized to a $\mathrm{pH}$ of 6.5 using $\mathrm{NaOH}$. The bacteria with the optimal performance were selected for fermentation of cucumber extract neutralized by HMC. The cucumber extract with initial $\mathrm{pH} 4.1$ was adjusted to $\mathrm{pH} 6.5$ by using $10 \mathrm{M}$ $\mathrm{NaOH}$ or HMC slurry. As observed, HMC was not dissolved entirely when the $\mathrm{pH}$ reached 6.5. Approximately $11 \mathrm{~g}$ of $\mathrm{HMC}$ was required for adjusting $1 \mathrm{~L}$ of cucumber juice to $\mathrm{pH} 6.5$. The $\mathrm{CO}_{2}$ gas formed during fermentation using HMC was removed by inserting needles at each sampling time. In all fermentation experiments, no additional nutrient or carbon sources were supplemented to cucumber extract.

To confirm lactic acid yield, the selected lactic acid bacteria were grown in MRS broth medium and synthetic cucumber extract. The synthetic cucumber extract was prepared by adding the relevant amount of detectable sugars and organic acids into deionized water. In addition, yeast extract, $\mathrm{KH}_{2} \mathrm{SO}_{4}$, $\mathrm{MgSO}_{4} \cdot 6 \mathrm{H}_{2} \mathrm{O}$, and $\mathrm{MnSO}_{4} \cdot 4 \mathrm{H}_{2} \mathrm{O}$ at the same concentration as in the MRS medium were added to ascertain the growth of lactic acid bacteria.

\subsection{Analytical Techniques}

The $\mathrm{pH}$ of the cucumber extract samples was measured using a compact $\mathrm{pH}$ meter (LAQUAtwin-pH-22, Horiba Scientific, Kyoto, Japan). The organic acid and sugar contents of the cucumber extract were determined by high-performance liquid chromatography (HPLC) using a Dionex Ultimate3000 high-performance liquid chromatography (ThermoFisher Scientific Inc., Waltham, MA, USA). The conditions of the HPLC are summarized in Table 1. Before subjected to HPLC, all samples were centrifuged at 10,000 rpm for $5 \mathrm{~min}$ to remove biomass and then filtrated through a $0.2-\mu \mathrm{m}$ syringe filter and serially diluted at the appropriate concentration for determination. 
Table 1. Conditions of high-performance liquid chromatography (HPLC) for analyzing sugars and organic acids.

\begin{tabular}{lll}
\hline \multicolumn{1}{c}{ Conditions } & \multicolumn{1}{c}{ Sugars } & \multicolumn{1}{c}{ Organic Acid } \\
\hline Column & YMC-Pack Polyamine II $(250 \times 4.6 \mathrm{~mm})$ & YMC-Triart C18 $(3 \mu \mathrm{m}, 12 \mathrm{~nm}), 150 \times 3.0 \mathrm{~mm}$ \\
Eluent & Acetonitrile/water $(75 / 25, v / v)$ & $20 \mathrm{mM} \mathrm{H} 3 \mathrm{PO} 4$ \\
Oven temp. & $26^{\circ} \mathrm{C}$ & $37^{\circ} \mathrm{C}$ \\
Flow rate & $1.0 \mathrm{~mL} / \mathrm{min}$ & $1.0 \mathrm{~mL} / \mathrm{min}$ \\
Detector & RI (Shodex RI-101, Tokyo, Japan) & $\mathrm{UV}$ at $220 \mathrm{~nm}$ \\
Inj. Volume & $20 \mu \mathrm{L}$ & $20 \mu \mathrm{L}$ \\
\hline
\end{tabular}

Inorganic elements, such as $\mathrm{Mg}, \mathrm{Na}, \mathrm{Ca}, \mathrm{K}, \mathrm{Fe}, \mathrm{V}, \mathrm{Ni}, \mathrm{Al}, \mathrm{B}, \mathrm{As}, \mathrm{Pb}, \mathrm{S}$, were analyzed using an inductively coupled plasma-atomic emission spectroscopy (ICP-AES; Activa, JY Horiba, France) at the Busan Center of the Korea Basic Science Institute (KBSI). The samples were serially diluted at an appropriate concentration before analysis.

\section{Results and Discussion}

\subsection{Organics Content in Cucumber Extract and Pasteurization.}

The bacterial enumeration of cucumber extract samples pasteurized at various temperatures and times indicated that at least $90^{\circ} \mathrm{C}$ for $5 \mathrm{~min}$ was required to kill all indigenous bacteria in cucumber extract (Table 2). The decrease in bacteria number was correlated with the increase in temperature. In addition to temperature, the treatment time was also important for pasteurization. At the same temperature, extended treatment time resulted in a lower number of bacteria. The pasteurization at $95^{\circ} \mathrm{C}$ for $1 \mathrm{~min}$ did not kill all bacteria, but pasteurization at $90{ }^{\circ} \mathrm{C}$ for 5 min could effectively sterilize the cucumber extract.

Table 2. Pasteurization test of cucumber extract.

\begin{tabular}{|c|c|c|}
\hline \multicolumn{2}{|c|}{ Treatment Condition } & \multirow{2}{*}{$\begin{array}{l}\text { Colony Forming Unit Per } \mathrm{mL} \\
(\mathrm{CFU} / \mathrm{mL}), \text { Mean } \pm \text { S.D, } \mathrm{n}=3\end{array}$} \\
\hline Temperature $\left({ }^{\circ} \mathrm{C}\right)$ & Time (min) & \\
\hline \multicolumn{2}{|c|}{ Non-treated CAF } & $(162.50 \pm 1.41) \times 10^{5}$ \\
\hline 63 & 30 & $121.50 \pm 4.95$ \\
\hline 72 & 1 & $119.50 \pm 12.02$ \\
\hline 75 & 1 & $110.50 \pm 3.5$ \\
\hline 75 & 5 & $88.00 \pm 14.14$ \\
\hline 80 & 1 & $70.00 \pm 7.07$ \\
\hline 80 & 5 & $12.00 \pm 1.14$ \\
\hline 85 & 1 & $46.00 \pm 7.07$ \\
\hline 85 & 5 & $4.00 \pm 1.14$ \\
\hline 90 & 1 & $37.50 \pm 4.94$ \\
\hline 90 & 5 & 0 \\
\hline 95 & 1 & $35.50 \pm 6.36$ \\
\hline 95 & 5 & 0 \\
\hline 95 & 10 & 0 \\
\hline 95 & 15 & 0 \\
\hline 95 & 20 & 0 \\
\hline 100 & 5 & 0 \\
\hline 100 & 10 & 0 \\
\hline 100 & 15 & 0 \\
\hline 100 & 20 & 0 \\
\hline 121 & 15 & 0 \\
\hline
\end{tabular}


After pasteurization at $90{ }^{\circ} \mathrm{C}$ for $5 \mathrm{~min}$, the chemical properties of cucumber extract did not change significantly (Table 3) ( $p$-value $<0.05)$. The HPLC results indicated that the main organic components in the cucumber extract were fructose, glucose, and citric acid. Fructose and glucose were sugar sources for lactic acid fermentation. Fructose and glucose concentrations in cucumber extract were similar to those in a previous report [5], which indicated that fructose concentration was higher than glucose. Glutamic acid, tartaric acid, malic acid, and ascorbic acid are minor compounds in the cucumber extract. Ascorbic acid (vitamin C) is well-known as an antioxidant [20] with a variety of benefits to the human skin. It is interesting that this cucumber extract contains approximately $11 \mathrm{~g} / \mathrm{L}$ of citric acid, which is considered as a beneficial ingredient in a magnesium gel product.

Table 3. Organic contents in cucumber extract before and after pasteurization at $90^{\circ} \mathrm{C}$ for $5 \mathrm{~min}$.

\begin{tabular}{cccccccc}
\hline $\begin{array}{c}\text { Cucumber Extract } \\
\text { Types Title }\end{array}$ & $\begin{array}{c}\text { Fructose } \\
(\mathrm{g} / \mathrm{L})\end{array}$ & $\begin{array}{c}\text { Glucose } \\
(\mathrm{g} / \mathrm{L})\end{array}$ & $\begin{array}{c}\text { Citric } \\
\text { Acid }(\mathrm{g} / \mathrm{L})\end{array}$ & $\begin{array}{c}\text { Glutamic } \\
\text { Acid }(\mathrm{g} / \mathrm{L})\end{array}$ & $\begin{array}{c}\text { Tartaric } \\
\text { Acid }(\mathbf{m g} / \mathrm{L})\end{array}$ & $\begin{array}{c}\text { Malic Acid } \\
(\mathbf{m g} / \mathrm{L})\end{array}$ & $\begin{array}{c}\text { Ascorbic } \\
\text { Acid }(\mathbf{m g} / \mathrm{L})\end{array}$ \\
\hline Before & 7.75 & 4.75 & 11.24 & 1.34 & 239.56 & 343.17 & 34.31 \\
After & 7.81 & 4.71 & 10.98 & 1.24 & 234.57 & 345.71 & 29.47 \\
\hline
\end{tabular}

\subsection{Fermentation of Original Cucumber Extract by Lactic Acid Bacteria}

Among the investigated bacteria, only Lactobacillus plantarum and Pediococcus acidilactici could perform fermentation of the original cucumber extract at the initial pH 4.1 (Figure 1). Glucose and fructose were consumed to produce lactic acid and a small amount of acetic acid. Citric acid was slightly consumed during fermentation. Final acetic acid accumulation in both fermentation cultures was 0.7 to $0.8 \mathrm{~g} / \mathrm{L}$. Fermentation in both cultures stopped when more than half of the glucose still remained in the cucumber extract. At the time of fermentation termination, $\mathrm{pH}$ was dropped to 3.3 in both cultures due to the production of lactic acid. The resulting low $\mathrm{pH}$ killed bacteria and terminated fermentation when sugars were accumulated. Sugar contents in other cultures were stable at steady state with the incubation time extended up to 14 days (data not shown) indicating that some of the investigated bacteria were not resistant to the original $\mathrm{pH}$ of cucumber extract ( $\mathrm{pH} 4.1)$.

Glucose and fructose utilization patterns in the two cultures were entirely different from each other. Both glucose and fructose were simultaneously fermented in the culture of Lactobacillus plantarum, whereas in the culture of Pediococcus acidilactici, fructose started to be consumed right after the depletion of glucose. Similar to a previous investigation [5], glucose utilization by Lactobacillus plantarum was slightly more rapid than fructose during the exponential fermentation phase. A higher amount of lactic acid $(10.2 \mathrm{~g} / \mathrm{L})$ was produced in the culture of Lactobacillus plantarum compared to that $(7.1 \mathrm{~g} / \mathrm{L})$ of Pediococcus acidilactici. However, citric acid in the culture of Lactobacillus plantarum was degraded more than that in the culture of Pediococcus acidilactici. The maximum lactic acid production in the culture of Pediococcus acidilactici was obtained after 7 days of fermentation, whereas it took only 3 days for Lactobacillus plantarum to achieve the maximum lactic acid production. Because $\mathrm{pH}$ was the critical factor which controlled fermentation efficiency, the cucumber extract was neutralized to improve sugar utilization and fermentation efficiency. 

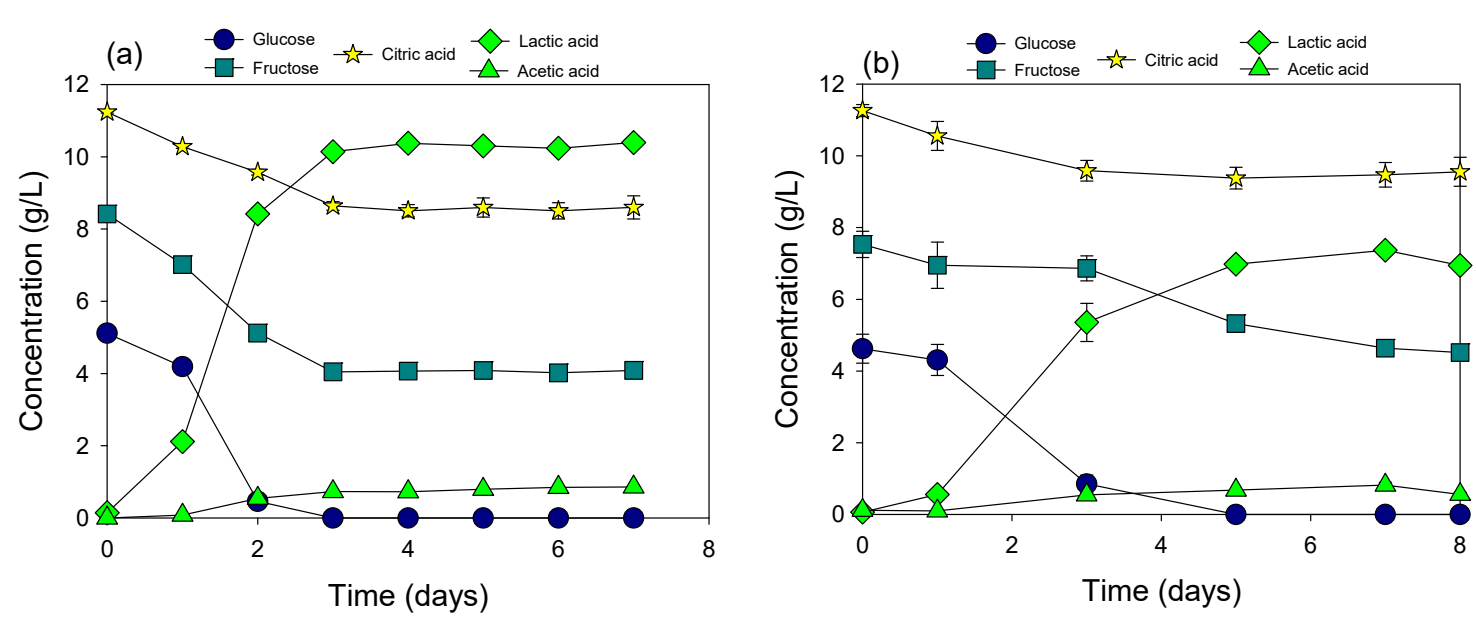

Figure 1. Fermentation of original cucumber extract by Lactobacillus plantarum (a) and Pediococcus acidilactici (b).

\subsection{Fermentation of Cucumber Extract Neutralized by $\mathrm{NaOH}$}

It is clear that neutralization of cucumber extract at the initial $\mathrm{pH} 6.5$ could improve fermentation efficiency in terms of both fermentation rate and sugar utilization (Figure 2). The $\mathrm{pH}$ of all cultures decreased to around 4.4 after 4 days of incubation, which is higher than the initial $\mathrm{pH}$ of cucumber extract. It took a shorter time to finish fermentation of natural sugars in cucumber juice. At $\mathrm{pH} 6.5$, all investigated bacteria could perform fermentation but with different fermentation rates and sugar utilization patterns. Based on the sugar utilization patterns, the applied bacteria could be divided into two groups. The first group includes Lactobacillus plantarum (Figure 2a), Lactobacillus casei KCTC 13086 (Figure 2h), and Lactobacillus paracasei KCTC 13169 (Figure 2i) which are all facultatively heterofermentative lactic acid bacteria that could simultaneously utilize both glucose and fructose to produce lactic acid. The second group includes Pediococcus acidilactici (Figure 2b), Lactobacillus acidophilus KCTC 3164 (Figure 2c), Lactobacillus delbrueckii subsp. lactis KCTC 3636 (Figure 2d), Lactococcus lactis subsp. lactis KCTC 2013 (Figure 2e), Lactobacillus salivarius subsp. salicinius KCTC 3600 (Figure 2f), and Lactobacillus helveticus KCTC 3545 (Figure 2g), which could only utilize fructose when all glucose was depleted. The higher acetic acid accumulation in the culture of Lactobacillus plantarum, Pediococcus acidilactici, and Lactobacillus helveticus KCTC 3545 was correlated with the higher degradation of citric acid in these cultures, indicating that acetic acid could be a product of citric acid degradation. The transformation of citric acid to acetic acid by lactic acid bacteria has also been reported previously [21].

Lactobacillus paracasei KCTC 13169 represented the best bacteria in terms of lactic acid production rate. Approximately $11.5 \mathrm{~g} / \mathrm{L}$ of lactic acid was produced in this culture only after 1 day of incubation. It was followed by Lactobacillus plantarum that produced $7.1 \mathrm{~g} / \mathrm{L}$ of lactic acid after 1 day of incubation. Both these bacteria obtained the maximum lactic acid production (12.5-13.1 g/L). In addition, Lactobacillus paracasei KCTC 13169 could ferment all natural sugars in cucumber extract and produce $12.1 \mathrm{~g} / \mathrm{L}$ of lactic acid after 2 days of incubation. Together with these three bacteria, Pediococcus acidilactici, which was highly resistant to low $\mathrm{pH}$, was selected for the fermentation of cucumber extract neutralized by HMC. 

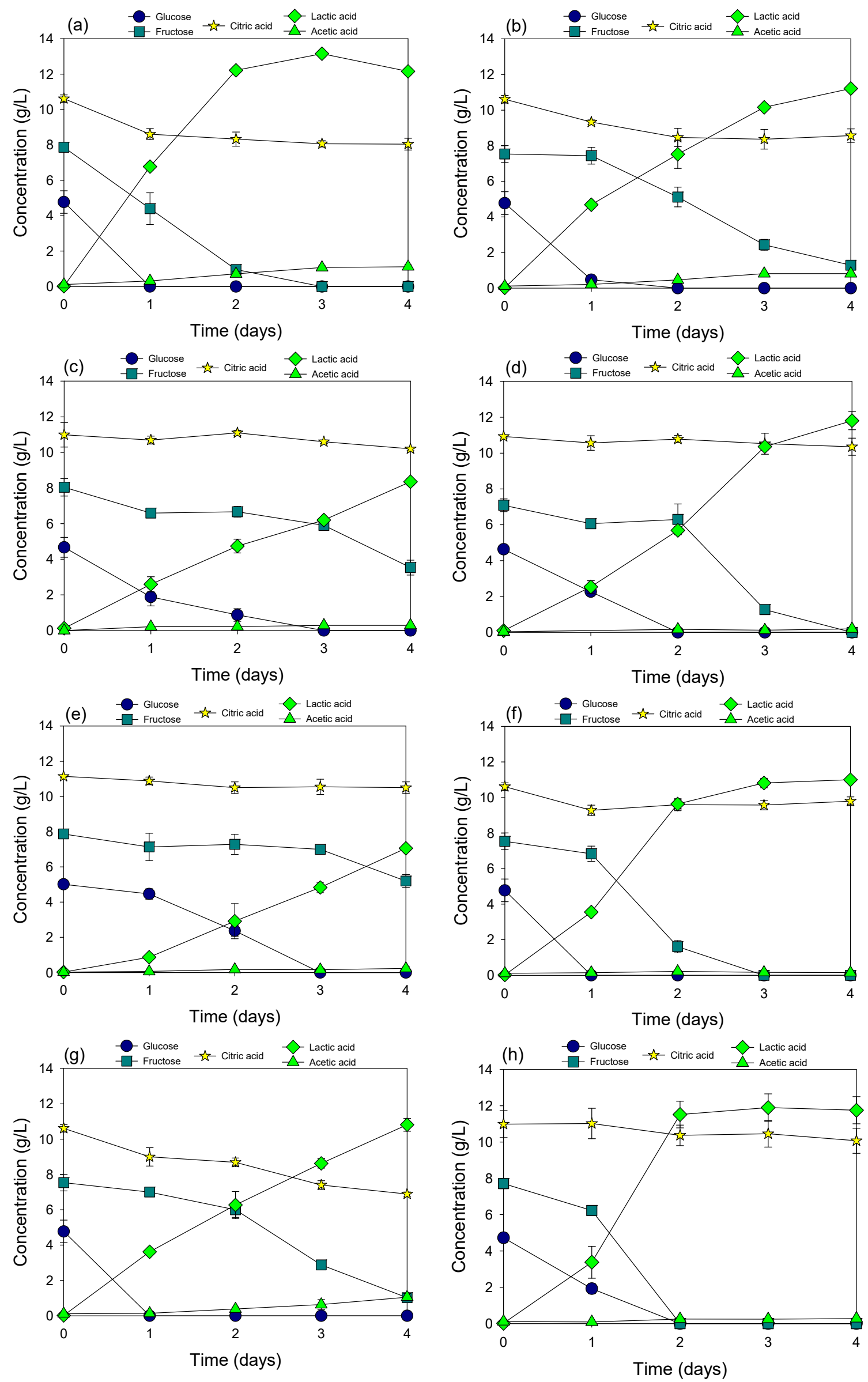

Figure 2. Cont. 


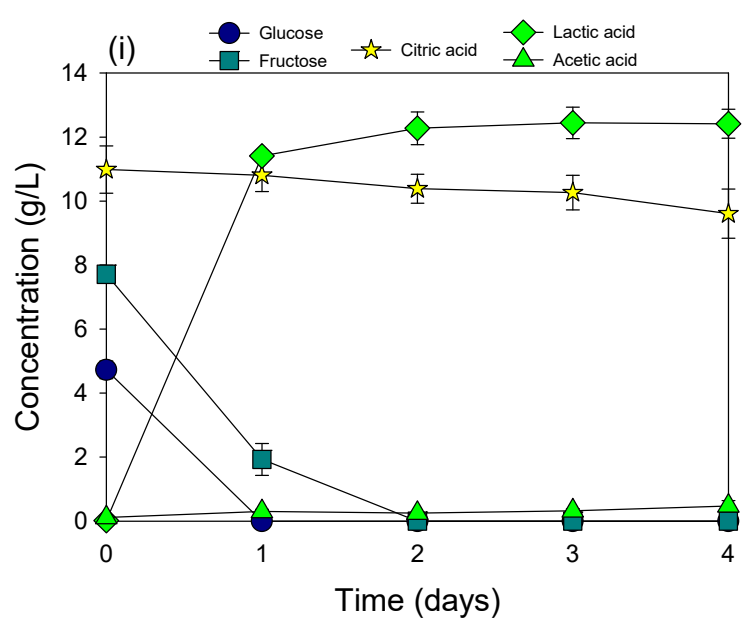

Figure 2. Fermentation of cucumber extract neutralized by $\mathrm{NaOH}$ using Lactobacillus plantarum (a), Pediococcus acidilactici (b), Lactobacillus acidophilus KCTC 3164 (c), Lactobacillus delbrueckii subsp. lactis KCTC 3636 (d), Lactococcus lactis subsp. lactis KCTC 2013 (e), Lactobacillus salivarius subsp. salicinius KCTC 3600 (f), Lactobacillus helveticus KCTC 3545 (g), Lactobacillus casei KCTC 13086 (h), and Lactobacillus paracasei KCTC 13169 (i).

\subsection{Fermentation of Cucumber Extract Neutralized by HMC}

HMC could be used as a neutralizing agent in the fermentation of cucumber extract (Figure 3). All sugars were totally consumed to produce lactic acid in all four cultures. Lactobacillus plantarum (Figure 2a) and Lactobacillus paracasei KCTC 13169 (Figure 2d) were the most efficient bacteria in this fermentation condition, which is indicated through lactic acid production and fermentation rate. Both bacteria could completely convert all sugars in cucumber extract to lactic acid within 2 days of incubation. Among them, Lactobacillus paracasei KCTC 13169 was slightly better than Lactobacillus plantarum in terms of fermentation rate. This well coincided with the result of fermentation of cucumber extract neutralized by $\mathrm{NaOH}$. Pediococcus acidilactici (Figure 2b) and Lactobacillus casei KCTC 13086 (Figure 2c) required 3 days for complete consumption of all sugars, and lactic acid production was much lower than those of the other two cultures.

There was a significant difference in citric acid degradation and acetic acid accumulation in the fermentation neutralized by $\mathrm{NaOH}$ and HMC. Higher citric acid degradation and more acetic acid accumulation occurred in the fermentation neutralized by HMC compared to those neutralized by $\mathrm{NaOH}$. This indicated that the presence of magnesium in the fermentation solution might accelerate the transformation of citric acid to acetic acid by fermenting bacteria [21], though the effect of various cations, including $\mathrm{Na}^{+}, \mathrm{K}^{+}, \mathrm{NH}_{4}{ }^{+}, \mathrm{Ca}^{2+}, \mathrm{Mg}^{2+}$, and $\mathrm{Mn}^{2+}$ on sugar utilization during cucumber juice fermentation was investigated [22]. The effect of magnesium on the transformation of citric acid in the fermentation solution is reported for the first time in this study. When lactic acid concentration reached the maximum value, the longer the incubation time was, the higher the rate of citrate breakdown into acetate. This fact was also supported by the change of the fermentation solution's $\mathrm{pH}$ (data not shown). The $\mathrm{pH}$ of fermentation was dropped from 6.5 to 4.4 after 2 days of incubation but increased back to 5.6 after 4 days of incubation. This was the limitation of fermentation neutralized by HMC, because citric acid, which is one of the $\alpha$-hydroxy acids, was proven to be a weak exfoliant and shows various benefits to human skin [23]. However, in industrial production, the fermentation could be optimized to stop right after lactic acid achieves the maximum concentration to minimize citric acid loss. 

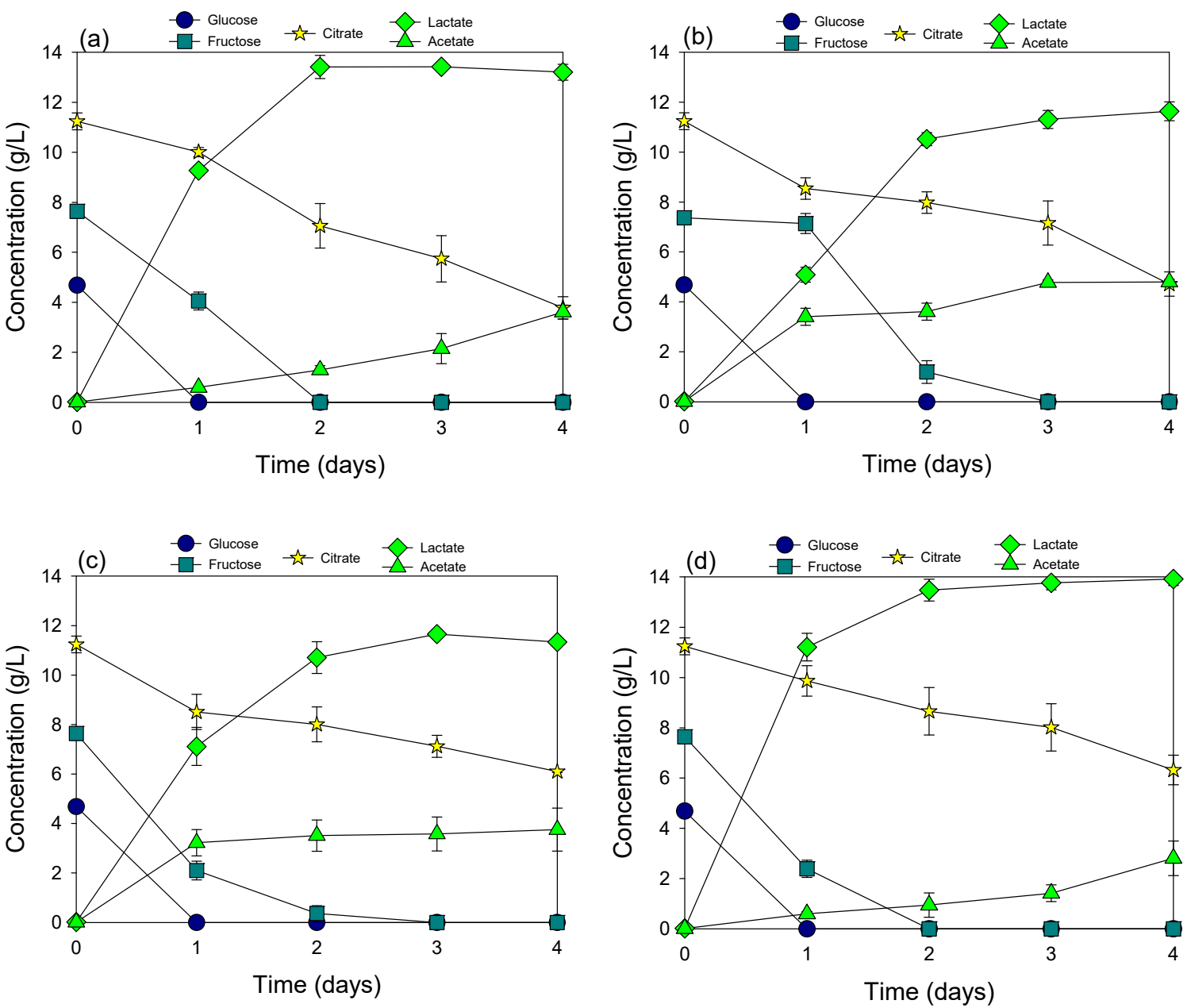

Figure 3. Fermentation of cucumber extract neutralized by HMC using Lactobacillus plantarum (a), Pediococcus acidilactici (b), Lactobacillus casei KCTC 13086 (c), and Lactobacillus paracasei KCTC 13169 (d).

Lactic acid production from cucumber extracts neutralized by HMC was even higher than that from extracts neutralized by $\mathrm{NaOH}$. Up to $13.5 \mathrm{~g} / \mathrm{L}$ and $13.9 \mathrm{~g} / \mathrm{L}$ of lactic acid were produced in the culture of Lactobacillus plantarum and Lactobacillus paracasei KCTC 13169, respectively, whereas the total sugar (glucose and fructose) content was only around $13 \mathrm{~g} / \mathrm{L}$. Mass balance of the fermentation system was not significantly affected by sampling because the total sample amount extracted from fermentation was tiny ( $<10 \%$ of total volume). Lactic acid yield in both of these cultures was higher than the maximum yield $(0.98 \mathrm{~g} / \mathrm{g})$ recorded previously by a mutant strain [24]. It is possible that other minor blind compounds, such as soluble starch, in the cucumber extract could contribute to lactic acid fermentation. The transformation of soluble starch to lactic acid by Lactobacillus spp. was well identified in the previous study $[25,26]$.

In fact, the growth of Lactobacillus plantarum and Lactobacillus paracasei KCTC 13169 in MRS medium, and synthetic cucumber juice again confirmed that other minor blind compounds contributed to fermentation of the pure cucumber juice (Figure 4). The lactic acid yield of Lactobacillus plantarum and Lactobacillus paracasei KCTC 13169 in the MRS medium was 0.94 and $0.93 \mathrm{~g} / \mathrm{g}$ of sugar consumed, respectively. MRS medium was considered as the best broth medium for the growth of lactic acid bacteria, and lactic acid yield in this medium was always the highest. The lactic acid yield of both cultures in synthetic cucumber extract was the same $(0.81 \mathrm{~g} / \mathrm{g}$ sugar consumed). This was much lower than that of the MRS medium. It was interesting that the fermentation rate of Lactobacillus plantarum in both MRS medium and synthetic cucumber extract was slightly higher than that of Lactobacillus paracasei KCTC 13169, which was contrary to the fermentation patterns of pure cucumber extract. 
The transformation of citric acid to acetic acid by Lactobacillus plantarum was also higher than that by Lactobacillus paracasei KCTC 13169.
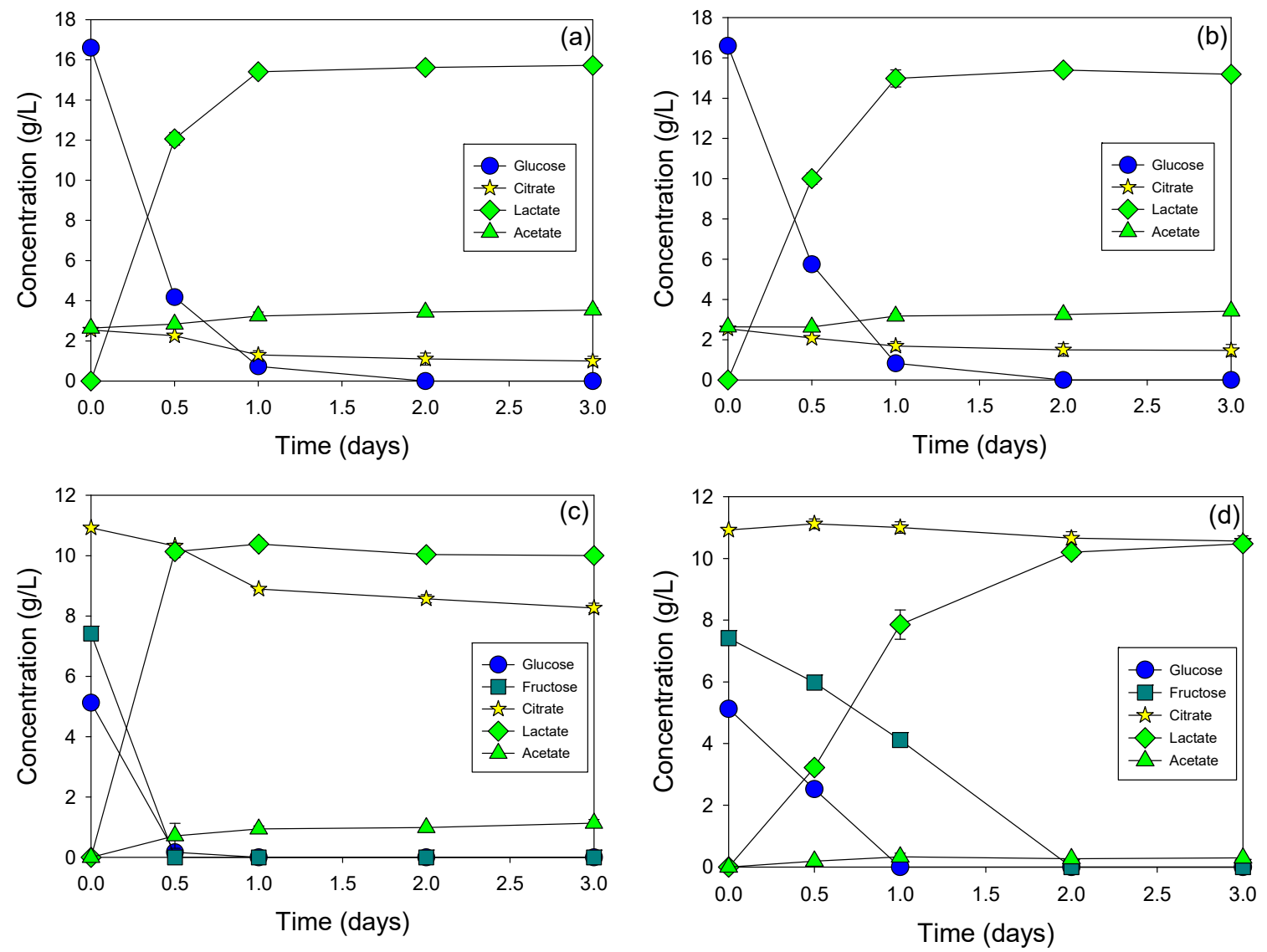

Figure 4. Growth of Lactobacillus plantarum (a) and Lactobacillus paracasei KCTC 13169 (b) in MRS medium and fermentation of synthetic cucumber extract by Lactobacillus plantarum (c) and Lactobacillus paracasei KCTC 13169 (d).

\subsection{Characterization of Final Products}

After 2 days of fermentation by Lactobacillus paracasei KCTC 13169 using HMC (12 g/L) as the neutralizing agent, the cucumber extract was introduced to the established pasteurization at $95{ }^{\circ} \mathrm{C}$ for $5 \mathrm{~min}$, followed by centrifugation at $8000 \mathrm{rpm}$ for $5 \mathrm{~min}$ to remove biomass. The final product was polished by filtering through a $0.45 \mu \mathrm{m}$ membrane. The final product was a clear yellowish liquid. Detectable chemical contents in the final product are shown in Table 4. Compared to the original cucumber extract, glucose and fructose were depleted, and lactic acid and acetic acid were newly produced. About $27.3 \%$ of citric acid was lost due to the degradation and transformation to acetic acid. The glutamic acid concentration was not significantly changed during the fermentation. Tartaric acid and malic acid increased after fermentation, which was desirable because these hydroxyl acids also benefit the skin. As a labile compound [27], only $1.93 \mathrm{mg}$ of ascorbic acid was retained in the fermented cucumber juice. After fermentation, the cucumber extract was deliberately supplemented with a significant amount of soluble magnesium ion, which could be transdermally absorbed and transferred into the bloodstream to recover aches and pains immediately. In addition to magnesium, the fermented cucumber extract also contained calcium, sodium, and potassium, which are originally present in cucumber fruit. Even though vitamin $C$ in cucumber extract was lost during fermentation, fermented cucumber extract was compensated with a range of compounds at high concentration, which have significant value in skincare. It can be said that the skincare value of fermented cucumber extract was 
substantially increased compared to the original cucumber extract that is already well-known for its benefit $[2,3]$.

Table 4. Detectable chemical contents in cucumber extract fermented by Lactobacillus paracasei KCTC 13169 using HMC as the neutralizing agent.

\begin{tabular}{lccccccc}
\hline Compounds & \multicolumn{7}{c}{ Chemical Content } \\
\hline \multirow{3}{*}{ Organics } & $\begin{array}{c}\text { Citric acid } \\
(\mathrm{mg} / \mathrm{L})\end{array}$ & $\begin{array}{c}\text { Lactic acid } \\
(\mathrm{mg} / \mathrm{L})\end{array}$ & $\begin{array}{c}\text { Acetic acid } \\
(\mathrm{mg} / \mathrm{L})\end{array}$ & $\begin{array}{c}\text { Glutamic } \\
\text { acid }(\mathrm{mg} / \mathrm{L})\end{array}$ & $\begin{array}{c}\text { Tartaric acid } \\
(\mathrm{mg} / \mathrm{L})\end{array}$ & $\begin{array}{c}\text { Malic acid } \\
(\mathrm{mg} / \mathrm{L})\end{array}$ & $\begin{array}{c}\text { Ascorbic } \\
\text { acid }(\mathrm{mg} / \mathrm{L})\end{array}$ \\
& 8154.1 & $13,921.3$ & 1170.1 & 1281.2 & 415.00 & 745.12 & 1.93 \\
\hline \multirow{2}{*}{ Inorganics } & $\mathrm{Mg}(\mathrm{mg} / \mathrm{L})$ & $\mathrm{Ca}(\mathrm{mg} / \mathrm{L})$ & $\mathrm{Na}(\mathrm{mg} / \mathrm{L})$ & $\mathrm{K}(\mathrm{mg} / \mathrm{L})$ & - & - & - \\
& 3124.2 & 133.9 & 88.3 & 2163.6 & - & - & - \\
\hline
\end{tabular}

\section{Conclusions}

Fermentation of cucumber extract using hydrated magnesium carbonate was successfully achieved without supplementing any additional nutrients to increase the skincare value of cucumber extract. The highest fermentation efficiency was obtained with Lactobacillus paracasei KCTC 13169, which can successfully convert all glucose and fructose present in cucumber extract to lactic acid. The fermentation of synthetic cucumber juice proved that there were some unknown compounds in cucumber extract that also contributed to fermentation and resulted in lactic acid production higher than that of total sugar content. The application of hydrated magnesium carbonate was limited by the transformation of citric acid to acetate. However, this can be prevented by optimizing the termination of fermentation right after all sugars are consumed. The inclusion of soluble organic acid-bound magnesium in the fermented cucumber extract at high concentration supported a novel application of this fluid as an ingredient of magnesium gels.

Author Contributions: Data curation, V.-T.L.; Investigation, H.Y.K.; Project administration, T.T. and T.C.; Writing—original draft, V.K.N.

Funding: This research was funded by EcoMag Ltd. and Abundant Natural Health Pty, Abundant Produce Ltd.

Acknowledgments: The authors would like to acknowledge Seongyong Yun, Donghee Lee, and Sunja Cho for their assistance during the experiment.

Conflicts of Interest: The authors declare no conflict of interest.

\section{References}

1. Balboa, E.M.; Soto, M.L.; Nogueira, D.R.; González-López, N.; Conde, E.; Moure, A.; Vinardell, M.P.; Mitjans, M.; Domínguez, H. Potential of antioxidant extracts produced by aqueous processing of renewable resources for the formulation of cosmetics. Ind. Crops Prod. 2014, 58, 104-110. [CrossRef]

2. Akhtar, N.; Mehmood, A.; Khan, B.A.; Mahmood, T.; Muhammad, H. Exploring cucumber extract for skin rejuvenation. Plants 2011, 10, 1206-1216.

3. Murad, H. Evaluating the potential benefits of cucumbers for improved health and skin care. J. Aging Res. Clin. Pract. 2012, 5, 10-12.

4. Lopes, L.B.; Speretta, F.F.F.; Bentley, M.V.L.B. Enhancement of skin penetration of vitamin K using monoolein-based liquid crystalline systems. Eur. J. Pharm. Sci. 2007, 32, 209-215. [CrossRef]

5. Lu, Z.; Fleming, H.P.; Mcfeeters, R.F. Differential Glucose and Fructose Utilization During Cucumber Juice Fermentation. J. Food Sci. 2001, 66, 162-166. [CrossRef]

6. Passos, F.V.; Fleming, H.P.; Ollis, D.F.; Hassan, H.M.; Felder, R.M. Modeling the specific growth rate of Lactobacillus plantarum in cucumber extract. Appl. Microbiol. Biotechnol. 1993, 40, 143-150. [CrossRef]

7. Stiller, M.J.; Bartolone, J.; Stern, R.; Smith, S.; Kollias, N.; Gillies, R.; Drake, L.A. Topical 8\% Glycolic Acid and 8\% L-Lactic Acid Creams for the Treatment of Photodamaged Skin. Arch. Dermatol. 1996, 132, 631. [CrossRef] 
8. Coudray, C.; Rambeau, M.; Feillet-Coudray, C.; Gueux, E.; Tressol, J.C.; Mazur, A.; Rayssiguier, Y. Study of magnesium bioavailability from ten organic and inorganic $\mathrm{Mg}$ salts in $\mathrm{Mg}$-depleted rats using a stable isotope approach. Magnes. Res. 2005, 18, 215-223. [PubMed]

9. Kappeler, D.; Heimbeck, I.; Herpich, C.; Naue, N.; Höfler, J.; Timmer, W.; Michalke, B. Higher bioavailability of magnesium citrate as compared to magnesium oxide shown by evaluation of urinary excretion and serum levels after single-dose administration in a randomized cross-over study. BMC Nutr. 2017, 3, 7. [CrossRef]

10. Johnson, S. The multifaceted and widespread pathology of magnesium deficiency. Med. Hypotheses 2001, 56, 163-170. [CrossRef]

11. Dong, J.-Y.; Xun, P.; He, K.; Qin, L.-Q. Magnesium intake and risk of type 2 diabetes: Meta-analysis of prospective cohort studies. Diabetes Care 2011, 34, 2116-2122. [CrossRef] [PubMed]

12. Sabatier, M.; Arnaud, M.J.; Kastenmayer, P.; Rytz, A.; Barclay, D.V. Meal effect on magnesium bioavailability from mineral water in healthy women. Am. J. Clin. Nutr. 2002, 75, 65-71. [CrossRef] [PubMed]

13. Halevy, S.; Giryes, H.; Friger, M.; Sukenik, S. Dead sea bath salt for the treatment of psoriasis vulgaris: A double-blind controlled study. J. Eur. Acad. Dermatol. Venereol. 1997, 9, 237-242. [CrossRef]

14. Chandrasekaran, N.; Sanchez, W.Y.; Mohammed, Y.H.; Grice, J.E.; Roberts, M.S.; Barnard, R.T. Permeation of topically applied Magnesium ions through human skin is facilitated by hair follicles. Magnes. Res. 2016, 29, $35-42$.

15. Rylander, R. Bioavailability of magnesium salts-A review. J. Pharm. Nutr. Sci. 2014, 4, 57-59. [CrossRef]

16. Walker, A.F.; Marakis, G.; Christie, S.; Byng, M. Mg citrate found more bioavailable than other Mg preparations in a randomised, double-blind study. Walker. Magnes. Res. 2003, 16, 183-191.

17. Tran, K.T.; Han, K.S.; Kim, S.J.; Kim, M.J.; Tran, T. Recovery of magnesium from Uyuni salar brine as hydrated magnesium carbonate. Hydrometallurgy 2016, 160, 106-114. [CrossRef]

18. USFDA. Pharmaceutical Microbiology Manual. Available online: https://www.fda.gov/files/about\%20fda/ published/Pharmaceutical-Microbiology-Manual.pdf (accessed on 10 April 2019).

19. Jorgensen, J.H.; Lee, J.C.; Alexander, G.A.; Wolf, H.W. Comparison of Limulus Assay, Standard Plate Count, and Total Coliform Count for Microbiological Assessment of Renovated Wastewater. Appl. Environ. Microbiol. 1979, 37, 928-931. [PubMed]

20. Cort, W.M. Antioxidant Properties of Ascorbic Acid in Foods. In Ascorbic Acid: Chemistry, Metabolism, and Uses; ACS Publication: Washington, DC, USA, 1982; pp. 533-550.

21. Shimazu, Y.; Uehara, M.; Watanabe, M. Transformation of Citric Acid to Acetic Acid, Acetoin and Diacetyl by Wine Making Lactic Acid Bacteria. Agric. Biol. Chem. 1985, 49, 2147-2157.

22. Lu, Z.; Fleming, H.P.; Mcfeeters, R.F.; Yoon, S.A. Effects of Anions and Cations on Sugar Utilization in Cucumber Juice Fermentation. J. Food Sci. 2002, 67, 1155-1161. [CrossRef]

23. Kornhauser, A.; Coelho, S.G.; Hearing, V.J. Applications of hydroxy acids: Classification, mechanisms, and photoactivity. Clin. Cosmet. Investig. Dermatol. 2010, 3, 135-142. [CrossRef] [PubMed]

24. Wang, Y.; Tashiro, Y.; Sonomoto, K. Fermentative production of lactic acid from renewable materials: Recent achievements, prospects, and limits. J. Biosci. Bioeng. 2015, 119, 10-18. [CrossRef] [PubMed]

25. John, R.P.; Anisha, G.S.; Nampoothiri, K.M.; Pandey, A. Direct lactic acid fermentation: Focus on simultaneous saccharification and lactic acid production. Biotechnol. Adv. 2008, 27, 145-152. [CrossRef] [PubMed]

26. Reddy, G.; Altaf, M.; Naveena, B.J.; Venkateshwar, M.; Kumar, E.V. Amylolytic bacterial lactic acid fermentation-A review. Biotechnol. Adv. 2008, 26, 22-34. [CrossRef]

27. Erdman, J.W.; Klein, B.P. Harvesting, Processing, and Cooking Influences on Vitamin C in Foods. In Ascorbic Acid: Chemistry, Metabolism, and Uses; ACS Publication: Washington, DC, USA, 1982; pp. 499-532.

(C) 2019 by the authors. Licensee MDPI, Basel, Switzerland. This article is an open access article distributed under the terms and conditions of the Creative Commons Attribution (CC BY) license (http://creativecommons.org/licenses/by/4.0/). 